\title{
Risk coping strategy and information delivery and market linkage services in agriculture farming in Morena district of Madhya Pradesh
}

\author{
MUNESH KUMAR SHAKYA, SONU JAIN AND P. S. BADAL
}

See end of the paper for authors' affiliations

Correspondence to : SONU JAIN

Banaras Hindu University, VARANASI (U.P.) INDIA Email:sonujain.karauli @ gmail.com

\section{Paper History :}

Received : 21.01.2015;

Revised : 28.01 .2015

Accepted : 15.02.2015
ABSTRACT: It is often said that agriculture production is a risky business, that is, it is subject to risk. This means that due to complexities of physical and economic systems, the outcomes of farmer's actions and production decisions are uncertain and many possible outcomes are usually associated with a single action or production plan. Three major types of risk in farming can be identified; yield, price and transaction risks. Institutions are mechanisms that are used to structure human interactions in the presence of uncertainty. This includes political risk, which is the risk associated with unfavorable policy changes. Other risks include: human or personal risks, asset risk and financial risk. Farmers implement ex-ante strategies because of lack of mechanisms to cope with risks. Natural hazards can be managed by irrigation, crop insurance and by growing resistant varieties. Market risks are managed by price stabilization programmes, provision information and credit subsidies, off-farm investment seems to be a viable option in risk management. Ex-post strategies include re-deploying labour, depleting food reserves on farm, drawing down on other savings and asset liquidation. This study is mainly concerned with innovation in economic context, specifically agricultural technological innovation. This is successful creation, development and marketing of new agricultural products or successful application of new techniques. Three major degrees of innovation namely incremental, radical and fundamental innovations. Primary data were collected from farmers by direct interview method with well structured, pre-tested schedule prepared exclusively for this study. Multi-stage sampling method was used to select sample households. Simple random sampling procedure was followed for selection of sample villages. Study revealed that the farmers were adopting many risk coping strategy in different situations. Farmers rear livestock, poultry along with crops. If farmers get information about new technologies then they may increase crop production and productivity. They may earn more income from livestock and poultry. The study identified the most prevalent risks facing agricultural households, their risk attitudes, the risk management strategies they employ and the role of off-farm investments in farm household risk management. Maximum agricultural households (59\%) reported that drought risk was the most serious and other risk viz., flooding, insect pest attack, marketing and storage risk which were facing by farmers were less prevalent. The farmers get information about new technologies, new variety and market price through news paper, KVK, farmer seminar, market and other farmers.

KEY WORDS : Risk coping, Strategy, Information delivery, Market linkage services, Agriculture farming

HOW TO CITE THIS PAPER : Shakya, Munesh Kumar, Jain, Sonu and Badal, P.S. (2015). Risk coping strategy and information delivery and market linkage services in agriculture farming in Morena district of Madhya Pradesh. Internat. Res. J. Agric. Eco. \& Stat., 6 (1) : 140-144. 